\title{
THE SABERMETRIC REVOLUTION
}


This page intentionally left blank 


\title{
THE SABERMETRIC REVOLUTION
}

ASSESSING THE GROWTH

OF ANALYTICS IN BASEBALL

\author{
BENJAMIN BAUMER \\ AND \\ ANDREW ZIMBALIST
}

\author{
$\overline{\text { PENN }}$ \\ UNIVERSITY OF PENNSYLVANIA PRESS \\ PHILADELPHIA
}


Copyright (C) 2014 University of Pennsylvania Press

All rights reserved. Except for brief quotations used for purposes of review or scholarly citation, none of this book may be reproduced in any form by any means without written permission from the publisher.

\author{
Published by \\ University of Pennsylvania Press \\ Philadelphia, Pennsylvania 19104-4112 \\ www.upenn.edu/pennpress \\ Printed in the United States of America \\ on acid-free paper
}

$\begin{array}{llllllllll}2 & 4 & 6 & 8 & 10 & 9 & 7 & 5 & 3 & 1\end{array}$

Baumer, Benjamin.

Library of Congress Cataloging-in-Publication Data

The sabermetric revolution : assessing the growth of analytics in baseball / Benjamin Baumer and Andrew Zimbalist. - 1st ed.

p. $\mathrm{cm}$.

Includes bibliographical references and index.

ISBN 978-0-8122-4572-1 (hardcover : alk. paper)

1. Baseball-Statistical methods. 2. Baseball-Mathematical models. I. Zimbalist, Andrew S. II. Title.

GV877.B38 2014

796.357021-dc23 
For all the left arms that made it, and all those that didn't 
This page intentionally left blank 